\title{
Brevibacterium paucivorans sp. nov., from human clinical specimens
}

University of Louvain, Faculty of Medicine, Microbiology Unit, UCL/5490, Av. Hippocrate 54, B-1200 Brussels, Belgium

\author{
Georges Wauters, Jacqueline Charlier, Michèle Janssens \\ and Michel Delmée
}

Author for correspondence: Georges Wauters. Tel: +32 2 7645490. Fax: +32 27649440.
e-mail: wauters@mblg.ucl.ac.be

\begin{abstract}
Seven isolates from various human body sites displayed general chemotaxonomic and phenotypic characteristics of the genus Brevibacterium. This was corroborated by the $16 \mathrm{~S}$ rRNA gene sequence analysis of strain CF62 ${ }^{\top}$, showing a sequence similarity of $99 \%$ to Brevibacterium mcbrellneri. However, DNA-DNA hybridization, a peculiar amino acid content of the cell wall and some phenotypic properties clearly suggested that these strains belong to a new species, for which the name Brevibacterium paucivorans sp. nov. is

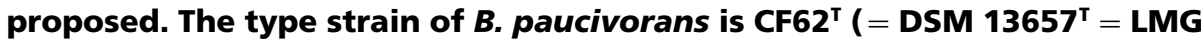
$\left.19814^{\top}\right)$. The DNA G+C content of the type strain is $55.8 \mathrm{~mol} \%$.
\end{abstract}

Keywords: Brevibacterium paucivorans, taxonomy

\section{INTRODUCTION}

Brevibacterium species have been encountered increasingly in humans, either as commensals or as opportunistic pathogens (Funke et al., 1997). Four species have been recognized in humans: Brevibacterium casei (Collins et al., 1983), Brevibacterium epidermidis (Collins et al., 1983), Brevibacterium mcbrellneri (McBride et al., 1993) and Brevibacterium otitidis (Pascual et al., 1996). Brevibacterium avium has been isolated from poultry (Pascual \& Collins, 1999). Brevibacterium iodinum (Collins et al., 1980) and Brevibacterium linens (Fiedler et al., 1981) are found mainly in food and in the environment. Brevibacterium liquefaciens has proved to be a synonym of Arthrobacter nicotianae (Stackebrandt et al., 1983) and three species, Brevibacterium halotolerans, Brevibacterium frigoritolerans and Brevibacterium stationis, have not been subjected to genetic studies and their taxonomic position is still uncertain.

Members of the genus Brevibacterium are characterized by an oxidative metabolism, a high proportion of branched cellular fatty acids, mainly anteiso 15:0 and anteiso 17:0, and a peptidoglycan type $\mathrm{A} 1 \gamma$ with meso-diaminopimelic acid as the diamino acid (Funke et al., 1997). We describe seven strains, displaying a peculiar cell wall composition, isolated from various

The EMBL accession number for the 16S rRNA gene sequence of strain CF62 ${ }^{\top}$ is AJ251463. human body sites. Their phenotypic, chemotaxonomic and genetic characteristics suggest that they all belong to a single species in the genus Brevibacterium, for which the name Brevibacterium paucivorans sp. nov. is proposed.

\section{METHODS}

Bacterial strains. The seven strains were isolated from various clinical specimens: CF41 from cerebrospinal fluid, CF45 from a groin abscess, $\mathrm{CF} 62^{\mathrm{T}}$ from blood, $\mathrm{CF} 67$ from an ear discharge, CF69 from an intravascular catheter, CF73 from a wound and CF89 from a groin swab. They were stored in glycerol at $-20^{\circ} \mathrm{C}$ and cultured on blood agar at $37^{\circ} \mathrm{C}$ in air for the purposes of the study. The following reference strains were included in the study for phenotypic comparison: B. casei ATCC $35513^{\mathrm{T}}$, DSM 9657 and DSM 9658, B. epidermidis ATCC 49089, DSM 9585 and DSM 9586, $B$. mcbrellneri DSM $9583^{\mathrm{T}}$ and DSM 9584, B. otitidis DSM 10718 ${ }^{\mathrm{T}}$, B. iodinum LMG 2201 and B. linens LMG 3915.

Phenotypic characterization. Most phenotypic characteristics were studied as outlined previously (Funke et al., 1997; Wauters et al., 1998, 2000). Acid production from 2,3butylene glycol was tested on medium containing the following $\left(1^{-1}\right): 1 \mathrm{~g}$ proteose peptone, $1 \mathrm{~g}$ yeast extract, $50 \mathrm{ml}$ 2,3-butylene glycol, $0.025 \mathrm{~g}$ phenol red and $17 \mathrm{~g}$ agar. The medium was dispensed in $2 \mathrm{ml}$ amounts in small tubes and distributed to slants after sterilization. Slants were inoculated heavily with bacteria from a $24 \mathrm{~h}$ blood agar plate and incubated for $4 \mathrm{~d}$. The medium turned yellow when acid was produced from the butylene glycol. Pyrazinamidase was detected on medium containing $10 \mathrm{~g}$ peptone and $2.5 \mathrm{~g} \mathrm{2-}$ pyrazine carboxamide $1^{-1}$ distilled water. One $\mathrm{ml}$ of the broth 
was inoculated heavily and incubated for $24 \mathrm{~h}$. Pyrazinoic acid was detected by adding one drop of a $1.0 \%(\mathrm{w} / \mathrm{v})$ solution of ferrous sulfate. Pyrrolidonyl arylamidase and $\alpha$ glucosidase were tested for by using diagnostic tablets (Rosco). Carbohydrate assimilation was performed on 50 $\mathrm{CH}$ strips using AUX medium (bioMérieux). API ZYM and API CORYNE (bioMérieux) strips were used according to the manufacturer's instructions, except for gelatin, which was read after up to $5 \mathrm{~d}$.

Antibiotic susceptibility. Susceptibility was evaluated by MIC determination using E-test strips (PDM, Solna, Sweden), on Mueller-Hinton blood agar incubated at $37^{\circ} \mathrm{C}$ for $24 \mathrm{~h}$. Penicillin, ampicillin, cefotaxime, cephalothin, erythromycin, ciprofloxacin, gentamicin and vancomycin were tested and the results were interpreted according to the criteria established for staphylococci by the National Committee for Clinical Laboratory Standards (1997).

Chemotaxonomic properties. Cellular fatty acids were assayed by GLC using a Delsi Chromatograph as described previously (Wauters et al., 1996). The amino acid composition of the peptidoglycan was studied by N. Weiss at the DSMZ (Braunschweig, Germany) using a TLC method as outlined by Schleifer \& Kandler (1972).

16S rRNA gene sequence determination. Sequence analysis was performed at the DSMZ by C. Sproër. Approximately $95 \%$ of the $16 \mathrm{~S}$ rRNA gene sequence of the strains was determined by direct sequencing of PCR-amplified 16S rDNA. Genomic DNA extraction, PCR-mediated amplification of the $16 \mathrm{~S}$ rDNA and purification of the PCR products were carried out as described previously (Rainey et al., 1996). Purified PCR products were sequenced using the ABI PRISM Dye Terminator cycle sequencing ready reaction kit (Applied Biosystems) according to the manufacturer's protocol. Sequence reactions were electrophoresed using an Applied Biosystems 373A DNA Sequencer. The resulting sequence data were put into the alignment editor ae2 (Maidak et al., 1996), aligned manually and compared with representative $16 \mathrm{~S}$ rRNA gene sequences of organisms belonging to the Corynebacterium subgroup of the Gram-positive bacteria (Maidak et al., 1996). For comparison, 16S rRNA sequences were obtained from the EMBL database or RDP (Maidak et al., 1996). 16S rRNA gene similarity values were calculated by pairwise comparison of the sequences within the alignment. For construction of the phylogenetic dendrogram, operations of the PHYLIP package (version 3.5.1; J. Felsenstein, Department of Genetics, University of Washington, Seattle, WA, USA) were used. Pairwise evolutionary distances were computed from percentage similarities by the correction of Jukes \& Cantor (1969) and, based on the evolutionary distance values, the phylogenetic tree was constructed by the neighbour-joining method (Saitou \& Nei, 1987). The root of the tree was determined by including the 16S rRNA gene sequence of Dermatophilus congolensis in the analysis.

DNA-DNA hybridization. DNA-DNA hybridization determinations were carried out at the DSMZ. DNA was isolated by chromatography on hydroxyapatite by the procedure of Cashion et al. (1977). DNA-DNA hybridization was performed as described by De Ley et al. (1970) with the modifications described by Huß et al. (1983) and Escara \& Hutton (1980), using a Gilford System model 2600 spectrometer equipped with a Gilford model 2527-R thermoprogrammer and plotter. Renaturation rates were computed with the TRANSFER.BAS program of Jahnke (1992).

\section{RESULTS AND DISCUSSION}

Gram staining of the seven strains showed short and plump coryneform rods. Colonies on blood agar reached $1-2 \mathrm{~mm}$ diameter after $48 \mathrm{~h}$ of incubation at $37^{\circ} \mathrm{C}$. They were opaque, glistening and smooth, but sometimes sticky. Aerobic growth was observed at 30 and $37^{\circ} \mathrm{C}$ but not at $20^{\circ} \mathrm{C}$. There was no sugar acidification, either fermentatively or oxidatively. Urease, nitrate reduction, indole production, decarboxylation of lysine and ornithine and arginine dihydrolase were negative. Gelatin was hydrolysed weakly and slowly but casein hydrolysis was negative. Tyrosine and xanthine hydrolysis were also negative. Ethylene glycol was acidified but 2,3-butylene glycol was not. Methanethiol production was positive. Pyrrolidone arylamidase and pyrazinamidase were negative. Using $50 \mathrm{CH}$ strips, no carbohydrates were assimilated. With the API ZYM system, only esterase lipase (C8), leucine arylamidase and phosphoamidase were positive in all strains; trypsin was positive in some strains. The API CORYNE code obtained with the seven strains was uniformly 0000004 .

The strains were susceptible to all antibiotics tested with the exception of strain CF73, which was resistant to gentamicin and ciprofloxacin.

The cellular fatty acids were predominantly of the branched type, predominantly anteiso $\mathrm{C} 15: 0$ and anteiso $\mathrm{C} 17: 0$, although the sum of the two components did not always reach $75 \%$ of the total cellular fatty acids, as is the rule in other brevibacteria (Funke et al., 1997).

The peptidoglycan analysis revealed the presence of meso-diaminopimelic acid as the diamino acid. A unique feature was the presence in the cell wall of an excess of glutamic acid and glycine, which could be removed by hydrofluoric acid treatment in the cold. This suggested that there was a non-peptidoglycan component containing glutamic acid and glycine that could be split off by hydrofluoric acid.

16S rRNA gene sequencing of CF $62^{\mathrm{T}}$ showed the highest similarity, $99 \%$, to B. mcbrellneri (Table 1), and the overall phenotypic and chemotaxonomic properties of strain $\mathrm{CF} 62^{\mathrm{T}}$ were consistent with its membership of the genus Brevibacterium (Funke et al., 1997). DNA-DNA hybridization between strain CF $62^{\mathrm{T}}$ and the type strain of B. mcbrellneri, DSM $9583^{\mathrm{T}}$, showed a relationship of $65.4 \%$. DNA of strains CF41, CF45, CF67 and CF69 displayed homology levels of $86 \cdot 3,89 \cdot 1,90 \cdot 2$ and $78 \cdot 5 \%$, respectively, with labelled DNA of $\mathrm{CF} 62^{\mathrm{T}}$, suggesting that they belong to a single species. The DNA G $+\mathrm{C}$ content of strain $\mathrm{CF} 62^{\mathrm{T}}$ was $55.8 \mathrm{~mol} \%$, which is rather low in comparison with other brevibacteria (Gruner et al., 1994).

Although the $65.4 \%$ DNA-DNA hybridization of CF $62^{\mathrm{T}}$ to B. mcbrellneri was rather close to the $70 \%$ limit required to conclude that they constitute different 
Table 1. 16S rRNA gene sequence similarity between $B$. paucivorans $\mathrm{CF}^{\top}{ }^{\top}$ and other Brevibacterium species and related taxa

\begin{tabular}{|lcc|}
\hline Species & Accession number & 16S rRNA similarity to CF62 $\mathbf{~}^{\text {(\%) }}$ \\
\hline Brevibacterium liquefaciens & AJ251417 & $92 \cdot 1$ \\
Brevibacterium casei & AJ251418 & $93 \cdot 4$ \\
Brevibacterium avium & $\mathrm{Y} 17962$ & $94 \cdot 0$ \\
Brevibacterium epidermidis & $\mathrm{X} 76565$ & $93 \cdot 8$ \\
Brevibacterium iodinum & $\mathrm{X} 83813$ & $93 \cdot 9$ \\
Brevibacterium linens & $\mathrm{X} 77451$ & $93 \cdot 8$ \\
Brevibacterium mcbrellneri & $\mathrm{X} 93594$ & $99 \cdot 0$ \\
Brevibacterium otitidis & $\mathrm{X} 93593$ & $94 \cdot 9$ \\
Kocuria rosea & $\mathrm{X} 87756$ & $92 \cdot 5$ \\
Nesterenkonia halobia & $\mathrm{X} 80747$ & $92 \cdot 0$ \\
Arthrobacter atrocyaneus & $\mathrm{X} 80746$ & $90 \cdot 9$ \\
Dermabacter hominis & $\mathrm{X} 91034$ & $91 \cdot 6$ \\
Dermatophilus congolensis & $\mathrm{M} 59067$ & $91 \cdot 8$ \\
\hline
\end{tabular}

Table 2. Characteristics that differentiate B. paucivorans from other Brevibacterium species

Taxa are identified as: 1, B. paucivorans; 2, B. mcbrellneri; 3, B. casei; 4, B. epidermidis; 5, B. otitidis; 6, B. iodinum; 7, B. linens. Characteristics are scored as: + , positive; - , negative; $(+)$, delayed positive; $+/-$, most strains positive; $-/+$, most strains negative; w, weak reaction; v, variable.

\begin{tabular}{|c|c|c|c|c|c|c|c|}
\hline Characteristic & 1 & 2 & 3 & 4 & 5 & 6 & 7 \\
\hline Colonies & $\begin{array}{l}\text { Greyish, smooth } \\
\text { or sticky }\end{array}$ & $\begin{array}{l}\text { Greyish, dry, } \\
\text { friable }\end{array}$ & $\begin{array}{l}\text { White-greyish, } \\
\text { smooth }\end{array}$ & $\begin{array}{l}\text { White-yellow, } \\
\text { smooth }\end{array}$ & $\begin{array}{l}\text { Yellowish, } \\
\text { smooth }\end{array}$ & $\begin{array}{r}\text { Greyish, } \\
\text { smooth }\end{array}$ & $\begin{array}{l}\text { Yellow, } \\
\text { smooth }\end{array}$ \\
\hline Growth at $20^{\circ} \mathrm{C}$ & - & - & + & + & - & + & + \\
\hline \multicolumn{8}{|l|}{ Hydrolysis of } \\
\hline Casein & - & + & + & + & + & + & + \\
\hline Gelatin & $(+)^{\mathrm{w}}$ & $+/(+)$ & + & + & + & + & + \\
\hline Nitrate reduction & - & - & $-/+$ & $+/-$ & - & + & + \\
\hline $\begin{array}{l}\text { Acid production from } \\
\text { 2,3-butylene glycol }\end{array}$ & - & + & - & - & - & - & - \\
\hline \multicolumn{8}{|l|}{ Utilization of: } \\
\hline D-Arabinose & - & - & + & - & - & - & - \\
\hline Mannitol & - & - & - & + & - & - & - \\
\hline Gluconate & - & - & + & + & - & - & - \\
\hline$\alpha$-Glucosidase & - & - & $+/-$ & - & - & - & - \\
\hline Pyrrolidone peptidase & - & - & $\mathrm{V}$ & - & + & - & - \\
\hline Pyrazinamidase & - & - & + & + & + & + & + \\
\hline
\end{tabular}

species, several chemotaxonomic and phenotypic properties indicate clearly that our strains belong to a species distinct from $B$. mcbrellneri. Indeed, the peculiar amino acid content of the cell wall is not a feature of $B$. mcbrellneri. The cell morphology and culture characteristics are also different: cells of the new strains are stained evenly and they are short and plump, whereas those of $B$. mcbrellneri are somewhat irregular and thin. The glistening smooth or sticky colonies of the strains are in sharp contrast to the dry and crumbly colonies of $B$. mcbrellneri (McBride et al., 1993). Biochemically, the study strains can be further differentiated from $B$. mcbrellneri by the lack of casein hydrolysis. Furthermore, acidification of 2,3-butylene glycol is absent in the new strains and in other brevibacteria, while it is positive in $B$. mcbrellneri, a feature unique to this species. In addition, gelatin hydrolysis is delayed and weaker than in other Brevibacterium species and depends on the technique used. The seven strains differ from $B$. otitidis by their lack of tyrosine hydrolysis and by the absence of pyrrolidonyl peptidase and pyrazinamidase. They are distinct from $B$. case $i$ and $B$. epidermidis by their inability to grow at $20{ }^{\circ} \mathrm{C}$ and to assimilate any carbohydrate in the $50 \mathrm{CH}$ system and by the lack of decomposition of casein, tyrosine and xanthine. The main characteristics that differentiate the new species from other brevibacteria are summarized in Table 2. 


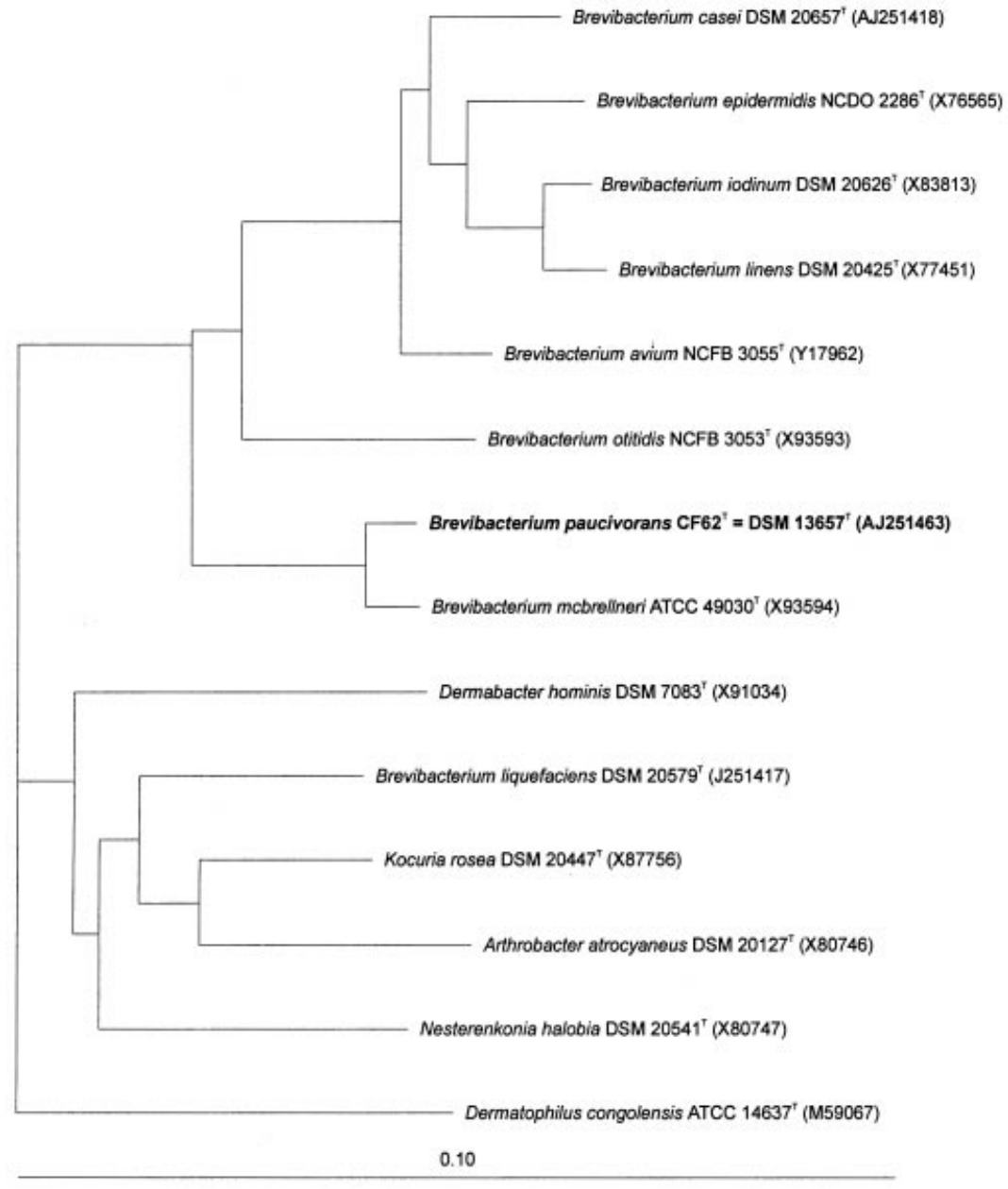

Fig. 1. Unrooted tree showing the phylogenetic position of $B$. paucivorans $\mathrm{CF}^{\top}{ }^{\top}$ within the genus Brevibacterium and related taxa. Bar, 10 nucleotide substitutions per 100 nucleotides.

There is genetic, chemotaxonomic and phenotypic evidence that strains CF62 ${ }^{\mathrm{T}}, \mathrm{CF} 41, \mathrm{CF} 45, \mathrm{CF} 67$ and CF69 belong to a single species in the genus Brevibacterium, distinct from the other species described in this genus and related most closely to $B$. mcbrellneri (Fig. 1). The name Brevibacterium paucivorans sp. nov. is proposed for this new species. Although strains CF73 and CF89 have not been subjected to genetic analysis, their chemotaxonomic and phenotypic properties suggest strongly that they belong to the new species.

The seven strains of B. paucivorans were isolated from different body sites, but no pathological role in disease was proved. The ecological niche of these organisms is not known and their clinical significance remains to be assessed.

\section{Description of Brevibacterium paucivorans sp. nov.}

Brevibacterium paucivorans (pau.ci.vo'rans. L. adj. paucus little; L. v. vorare to eat; N.L. adj. paucivorans eating little, because few substrates are assimilated).

Cells are Gram-positive, non-motile, non-sporulating, short and plump rods with a diphtheroid arrangement.
Colonies are greyish, glistening and smooth or sticky and approximately $2 \mathrm{~mm}$ in diameter after $48 \mathrm{~h}$ of incubation at $37^{\circ} \mathrm{C}$ on blood agar. Growth occurs aerobically at $37^{\circ} \mathrm{C}$ but not at $20^{\circ} \mathrm{C}$. Catalase is positive. No carbohydrates are acidified or assimilated. Urease and pyrazinamidase are negative and nitrate is not reduced. Methanethiol is produced. Casein, tyrosine, xanthine and aesculin are not hydrolysed. Gelatin is liquefied weakly and slowly. Ethylene glycol is acidified but 2,3-butylene glycol is not. Pyrrolidonyl peptidase is negative. Using the API ZYM system, leucine arylamidase and phosphoamidase are positive, esterase lipase $(\mathrm{C} 8)$ is weakly positive and trypsin is positive in some strains. Alkaline phosphatase, esterase (C4), lipase (C14), valine arylamidase, cystine arylamidase, $\alpha$-chymotrypsin, acid phosphatase, $\alpha$ - and $\beta$ galactosidase, $\beta$-glucuronidase, $\alpha$ - and $\beta$-glucosidase, $N$-acetyl- $\beta$-glucosaminidase, $\alpha$-mannosidase and $\alpha$ fucosidase are negative. Cellular fatty acids are of the branched type, with anteiso 15:0 and anteiso 17:0 being the major components. The diamino acid of the peptidoglycan is meso-diaminopimelic acid and the cell wall contains an excess of glutamic acid and glycine that are not bound to the peptidoglycan. The organisms are isolated from various human body sites. 
The type strain is $\mathrm{CF} 62^{\mathrm{T}}$ (= DSM $13657^{\mathrm{T}}=\mathrm{LMG}$ $\left.19814^{\mathrm{T}}\right)$. Three other strains have been deposited in the DSMZ: CF45 (= DSM 13658), CF67 (= DSM 13659) and CF69 (= DSM 13660). The G + C content of the DNA of the type strain is $55.8 \mathrm{~mol} \%$. It was isolated from human blood.

\section{REFERENCES}

Cashion, P., Holder-Franklin, M. A., McCully, J. \& Franklin, M. (1977). A rapid method for the base ratio determination of bacterial DNA. Anal Biochem 81, 461-466.

Collins, M. D., Jones, D., Keddie, R. M. \& Sneath, P. H. A. (1980). Reclassification of Chromobacterium iodinum (Davis) in a redefined genus Brevibacterium (Breed) as Brevibacterium iodinum nom. rev.; comb. nov. J Gen Microbiol 120, 1-10.

Collins, M. D., Farrow, J. A. E., Goodfellow, M. \& Minnikin, D. E. (1983). Brevibacterium casei sp. nov. and Brevibacterium epidermidis sp. nov. Syst Appl Microbiol 4, 388-395.

De Ley, J., Cattoir, H. \& Reynaerts, A. (1970). The quantitative measurement of DNA hybridization from renaturation rates. Eur J Biochem 12, 133-142.

Escara, J. F. \& Hutton, J. R. (1980). Thermal stability and renaturation of DNA in dimethyl sulfoxide solutions: acceleration of the renaturation rate. Biopolymers 19, 1315-1327.

Fiedler, F., Schäffler, M. J. \& Stackebrandt, E. (1981). Biochemical and nucleic acid hybridisation studies on Brevibacterium linens and related strains. Arch Microbiol 129, 85-93.

Funke, G., von Graevenitz, A., Clarridge, J. E., III \& Bernard, K. A. (1997). Clinical microbiology of coryneform bacteria. Clin Microbiol Rev 10, 125-159.

Gruner, E., Steigerwalt, A. G., Hollis, D. G., Weyant, R. S., Weaver, R. E., Moss, C. W., Daneshvar, M., Brown, J. M. \& Brenner, D. J. (1994). Human infections caused by Brevibacterium casei, formerly CDC groups B-1 and B-3. J Clin Microbiol 32, 1511-1518.

Huß, V. A. R., Festl, H. \& Schleifer, K. H. (1983). Studies on the spectrometric determination of DNA hybridization from renaturation rates. Syst Appl Microbiol 4, 184-192.

Jahnke, K.-D. (1992). Basic computer program for evaluation of spectroscopic DNA renaturation data from Gilford System 2600 spectrometer on a PC/XT/AT type personal computer. $J$ Microbiol Methods 15, 61-73.

Jukes, T. H. \& Cantor, C. R. (1969). Evolution of protein molecules. In Mammalian Protein Metabolism, pp. 21-132. Edited by H. N. Munro. New York: Academic Press.

McBride, M. E., Ellner, K. M., Black, H. S., Clarridge, J. E. \& Wolf, J. E. (1993). A new Brevibacterium sp. isolated from infected genital hair of patients with white piedra. J Med Microbiol 39, 255-261.

Maidak, B. L., Olsen, G. J., Larsen, N., Overbeek, R., McCaughey, M. J. \& Woese, C. R. (1996). The Ribosomal Database Project (RDP). Nucleic Acids Res 24, 82-85.

National Committee for Clinical Laboratory Standards (1997). Minimum inhibitory concentration (MIC) interpretative standards $\left(\mu \mathrm{g} \mathrm{ml}^{-1}\right)$ for organisms other than Haemophilus spp., Neisseria gonorrhoeae, and Streptococcus spp. NCCLS document M7-A4. Wayne, PA: National Committee for Clinical Laboratory Standards.

Pascual, C. \& Collins, M. D. (1999). Brevibacterium avium sp. nov., isolated from poultry. Int J Syst Bacteriol 49, 1527-1530.

Pascual, C., Collins, M. D., Funke, G. \& Pitcher, D. G. (1996). Phenotypic and genotypic characterization of two Brevibacterium strains from the human ear: description of Brevibacterium otitidis sp. nov. Med Microbiol Lett 5, 113-123.

Rainey, F. A., Ward-Rainey, N., Kroppenstedt, R. M. \& Stackebrandt, E. (1996). The genus Nocardiopsis represents a phylogenetically coherent taxon and a distinct actinomycete lineage: proposal of Nocardiopsaceae fam. nov. Int J Syst Bacteriol 46, 1088-1092.

Saitou, N. \& Nei, M. (1987). The neighbor-joining method: a new method for reconstructing phylogenetic trees. Mol Biol Evol 4, 406-425.

Schleifer, K. H. \& Kandler, O. (1972). Peptidoglycan types of bacterial cell walls and their taxonomic implications. Bacteriol Rev 36, 407-477.

Stackebrandt, E., Fowler, V. J., Fiedler, F. \& Seiler, H. (1983). Taxonomic studies on Arthrobacter nicotianae and related taxa: description of Arthrobacter uratoxydans sp. nov. and Arthrobacter sulfureus sp. nov. and reclassification of Brevibacterium protophormiae as Arthrobacter protophormiae comb. nov. Syst Appl Microbiol 4, 470-486.

Wauters, G., Driessen, A., Ageron, E., Janssens, M. \& Grimont, P. A. D. (1996). Propionic acid-producing strains previously designated as Corynebacterium xerosis, C. minutissimum, $C$. striatum, and $\mathrm{CDC}$ group $\mathrm{I}_{2}$ and group $\mathrm{F}_{2}$ coryneforms belong to the species Corynebacterium amycolatum. Int $J$ Syst Bacteriol 46, 653-657.

Wauters, G., Van Bosterhaut, B., Janssens, M. \& Verhaegen, J. (1998). Identification of Corynebacterium amycolatum and other nonlipophilic fermentative corynebacteria of human origin. $J$ Clin Microbiol 36, 1430-1432.

Wauters, G., Charlier, J., Janssens, M. \& Delmée, M. (2000). Identification of Arthrobacter oxydans, Arthrobacter luteolus sp. nov., and Arthrobacter albus sp. nov., isolated from human clinical specimens. J Clin Microbiol 38, 2412-2415. 